\title{
Syvyyttä työssä ja työyhteisössä oppimisen ymmärtämiseen
}

Järvinen, Annikki, Koivisto, Tapio \& Poikela, Esa (2000). Oppiminen työssä ja työyhteisössä. Porvoo - Helsinki Juva. 252 s. WSOY

Teos on yksi kolmesta Tampereen yliopiston asiantuntijoiden vastikään julkaisemasta aikuiskasvatuksen oppimateriaaliksi tarkoitetusta kirjasta. Tämän kirjan tekijöiden yhteistyön taustalla on Suomen Akatemian Koulutuksen vaikuttavuus -tutkimusohjelma. Kirja käsittelee työssä ja työyhteisössä oppimisen sekä työyhteisöjen ja organisaatioiden oppimisen problematiik- kaa lähinnä oppimisteorioiden ja organisaatiososiologian näkökulmasta. Tarvetta tällaiselle eri näkökulmia yhdistelevälle ja toisiinsa suhteuttavalle oppikirjalle on varmasti ollut.

Teos sisältää lyhyen johdannon lisäksi viisi varsinaista lukua. Aluksi esitellään tiivistetysti työnjaon ja työn organisoinnin keskeistä käsitteistöä sekä erilaisia lähestymistapoja näihin. Tällaisia näkökulmia ovat erityisesti byrokraattinen organisaatioteoria, taylorismi, humanisointiliike ja prosessijohtaminen. Tarkastelussa joudutaan väkisinkin tekemään monia rajauksia. Jakso antaa "työn organisoinnin ajankoh- taisia kehityssuuntia" tarkastellessaan erityisen paljon tilaa kevyestä (lean) tuotannosta käydylle keskustelulle, jota kautta näkökulma on paljolti teollisuustuotannossa. Palvelualojen kehitystä tarkastellaan muun muassa mcdonaldoitumista koskevan teesin kautta. Työn organisoinnin ristiriitaiset kehityssuunnat ja -mahdollisuudet tuodaan hyvin esiin. Kokonaisuutena jakso luo hyvän katsauksen viime vuosina esitettyihin näkökulmiin työn muuttumisesta, mutta eri näkökulmien keskinäistä suhdetta käsitteellisellä tasolla ei juuri pohdita. Kyse on ensisijaisesti eri näkökulmien yleisesittelystä eikä niiden kriittisemmästä arvioin- 
nista tai suhteutuksesta toisiinsa.

\section{Seuraavaksi teos}

tarkastelee oppimista ja sen luonnetta työn ja toiminnan yhteydessä. Jakso alkaa katsauksella informaation ja tiedon sekä yksityiskohtaisemmin ammatillisen ja organisationaalisen tiedon käsitteiden eroihin. Tästä edetään tarkastelemaan keskeisiä oppimisteoreettisia suuntauksia (behaviorismi, kognitivismi, eksperientalismi ja humanismi), niiden käytännön muotoja, kohdetta ja metaorientaatiota (transmissio, transaktio vai transformaatio). Jakso on kirjoitettu havainnollisesti ja jäsennelty hyvin. Tämän jälkeen tarkastelua syvennetään viiteen teoriaan, joilla kuvataan oppimista työssä, työyhteisössä ja työorganisaatiossa. Työssä oppimista kontekstualisoidaan Poikelan väitöskirjan mukaisella jaottelulla työtoiminnan orientaatioista, joita erotetaan neljä: tilanne-, toiminta-, kehittämis- ja tavoiteorientaatio. Tätä kautta luodaan malli oppimisen ja osaamisen tuottamisesta työorganisaatiossa. Poikelan väitöskirjatyöhön pitkälti perustuva jakso on lukijan kannalta ehkä kirjan vaativin.

\section{Kahdessa seuraavassa} luvussa tarkastellaan tietoa, tiedon prosessointia ja oppimisen organisointia työorganisaatiossa. Teoksessa esitetään malli tiedon eri lajeista ja siitä, miten ne kiinnittyvät organisaation erityyppisiin resursseihin. Jaottelu antaa havainnollisen kuvan tiedon moninaisesta varastoitumisesta ja ilmentymisestä organisaatiossa ja sen eri resurssityypeissä, joita ovat fyysiset resurssit, yksilöt, yhteisö sekä tietämysja tietokannat. Erilaisten tiedon lajien tärkeyden todetaan myös vaihtelevan erityyppisissä organisaatioissa. Tärkeimpinä organisaatioita erottelevina tekijät pitävät sitä, onko painotus organisaation jäsenten kollektiivisissa vai avainhenkilöiden suorituksissa sekä, onko se tuttujen vai uusien ongelmien ratkaisemisessa. Tietämyksen luomisen käsittelyssä hyödynnetään Nona-kan ja Takeuchin tunnettua mallia hiljaisen (tacit) ja ekplisiittisen tiedon sisäisen ja keskinäisen muuntumisen dynamiikasta. Tämä perusrakenteeltaan havainnollinen, mutta samalla yksinkertainen malli on jo aiemmin esitetty monessa suomalaisessa julkaisussa.

\section{Oppimisen organisoimista} työyhteisössä tekijät tarkastelevat puolestaan kolmen mallin kautta. Oppimisen verkostomallin painopiste on työntekijöiden itse organisoimissa toimintakäytäntöjä kehittävissä oppimisprojekteissa ja sitä voidaan soveltaa monentyyppisissä organisaatioissa. Oppimisen suunnitelmamalli soveltuu aloittelevan työntekijän vähittäiseen ohjaamiseen tavoitteena täysivaltaisen asiantuntijan asema työyhteisössä erityisesti kokeneen työntekijän opastuksella. Malli soveltuu organisaatioihin, joissa painotus on organisaation jäsenten kollektiivisissa suorituksissa. Kolmas malleista, strukturoitu työssä oppimisen ohjausmalli (STO), yhdistää formaalin koulutuksen idean työn yhteydessä tapahtuvaan oppimiseen. Laaja-alaisesti ja systemaattisesti sovellettuna malli luo pohjaa jatkuvalle laadun parantamiselle organisaa- tiossa. Kukin malli esitetään kirjassa varsin yksityiskohtaisesti ja monipuolisesti.

\section{Kirjan viimeisessä luvussa} painopiste siirtyy jälleen organisaatiososiologian puolelle. Tarkastelun kohteena on organisaatioiden ja niiden muodostamien verkostojen toimintakäytäntöjen uudistaminen ja kehittäminen. Teoksessa hyödynnetään Helsingin yliopiston Toiminnan teorian ja kehittävän työntutkimuksen yksikön tutkijoiden analyysia rajanylitysten merkityksestä organisaatioiden uusien toimintatapojen kehittämisessä. Lähtökohtana siinä on käsitys, että kollektiiviseen oppimiseen ei riitä vain perinteisen ammatillisen koulutuksen tehostaminen, vaan se edellyttää rajojen ylittämistä organisaatiossa suunnittelun ja toteutuksen kesken, strategisen ja operatiivisen kehittämisen kesken sekä organisaation ja sen ympäristön rajapinnan yli. Keskeisenä yritysten kehitystoiminnan tarkastelun analyyttisena välineenä tuodaan esiin kehittämisorganisaation käsite eli käsitys siitä, että kehitystoiminta vaatii tuotantotoimintaan verrattuna toisenlaisia tukirakenteita ja organisoitumismuotoja.

\section{Konkreettisina}

esimerkkeinä kehittämisorganisaatiosta sekä kehitystoiminnan lähestymistavoista ja malleista esitetään japanilainen laatupiiriorganisaatio, pohjoismainen tasavertainen vuoropuhelu, Toiminnan teorian ja kehittävän työntutkimuksen yksikön muutoslaboratorio ja erilaisia pilotointi- ja simulointi-malleja. Metallityöväen Murikka-opiston kehittämiskoulutusta käyte- 
tään Koiviston väitöskirjan pohjalta käytännön esimerkkinä osallistuvan suunnittelun soveltamisesta yrityksen kehitystoiminnassa.

\section{Kirja on kokonaisuutena} hyvä läpileikkaus työssä ja työyhteisössä tapahtuvan oppimisen problematiikkaan ja sopii tässä mielessä oppimateriaaliksi monellekin vaativuustasolle. Kirjan informaatiosisältö on runsas. Se esittelee useita ajankohtaisia näkökulmia, teorioita ja tutkimustuloksia sisältäen samalla var- sin kattavan lähdeluettelon eri teemoista enemmän kiinnostuneille lukijoille. Kolmen eri henkilön osallistuminen kirjoittamiseen näkyy jonkin verran tekstiasussa. Luvut ovat vaikeusasteeltaan erilaisia. Organisaatiososiologisesti painottuneissa luvuissa pyritään lähinnä kuvailuun. Sen sijaan taas esimerkiksi oppimisen kontekstualisuutta tarkasteltaessa rakennetaan ekplisiittinen analyyttinen viitekehys asian ympärille.

\section{Lukuja olisi voinut}

kytkeä jonkin verran enemmän toisiinsa, vaikka teos eteneekin loogisesti. Loppuun olisi kaivannut pidemmälle vietyä jäsennystä. Teos päättyy nyt ranskalaisina viivoina kirjoitettuun yhteenvetoon ja arviointiin yksittäisen teollisuuslaitoksen hitsaamon modernisointiprojektista. Tiedonnälkäisen ja -janoisen lukijan olisi voinut palkita vielä lopussa eri lukujen punaisia lankoja toisiinsa nivovalla yhteenvedolla.

Tuomo Alasoini

\section{Ajatuksia esitellystä teoksesta}

\begin{abstract}
Annikki Järvisen, Tapio
Koiviston ja Esa Poikelan kirjan Oppiminen työssä ja työyhteisössä motivaatio on ajankohtainen ja tärkeä. Organisaatioiden kehittämisen keskusteluissa on edetty vaiheeseen, jossa sekä organisation henkilöstön, prosessien ja teknologioiden kehittäminen on nähtävä yhtenäisenä haasteena. Monissa kehittämishankkeissa on törmätty ongelmiin, jotka johtuvat pääosin puutteellisesti valmistelluista uusien toimintatapojen omaksumusprosesseista, heikosti suunnitelluista ja viestityistä työnkuvista ja niiden kytkennöistä tietotekniikan hyväksikäyttöön. Järvisen et al kirja työssä oppimisesta antaa näiden kysymysten ratkaisuun oivalliset lähtökohdat.
\end{abstract}

\footnotetext{
Kirja sisältää hyvää aineistoa niistä teorioista ja lähestymistavoista, jotka on välttämätöntä ymmärtää osana organisaatioden ja työn kehittämistä. Erityisen tärkeää on
}

ymmärtää organisaatioperspektiivi, koska ns. liberalisation-koulukunnan näkemys ei pelkästään toimi nykyisessä työn kentässä. Uskon että tälle kirjalle löytyy laaja lukijakunta.

\section{Kirjan tärkeimpänä antina} pidän sen käyttökelpoisuutta organisaatiokehittäjien työkaluksi. Työssä oppimisen lähestymistavat tulevat entistä tärkeämmiksi organisaatioiden työkiireiden ja hiljaisen tiedon levittämisen vuoksi. Samalla perinteisten koulutusorganisaatioiden on muutettava toimintatapaansa yhä organisaatioläheisemmäksi, jolloin kunkin työntekijän työprosessien kuvaaminen ja ymmärtäminen tulevat entistä tärkeämmäksi. Organisaatiot toimivat myös usein erittäin kilpailuintensiivisessä ympäristössä, mikä edellyttää myös organisaatio-tason oppimisen tehokasta siirtoa ryhmä- ja yksilötasolla.
Kirjassa esitettyä Poikelan työorientaatioiden luokittelua tilanne-, toiminta-, kehittämis- ja tavoiteorientaatioihin pidän käyttökelpoisena sekä työntekijän oman reflektion tukemisessa, mutta myös esimies-alais -suhteiden kehittämisessä. Voimakkaan kehittämis- ja tavoiteorientaation omaavat henkilöt eivät useinkaan viihdy ns. rutiinitehtävissä. Toisaalta on turha odottaa organisaation kaikilta työntekijöiltä voimakasta kehittämispanosta ja sitoutumista uusiin tavoitteisiin. Oman työn analyysi ja toimenkuvien suunnittelu saavat tästä orientaatioluokittelusta hyvän työkalun.

Luvussa 3 tuodaan esille eri työssä oppimisen kontekstit, jotka limittyvät yksilöllisen, ryhmä- ja organisaatiooppimisen kenttiin. Kirjoittajat tunnistavat kolme keskeistä oppimisen tapaa: palautteesta, arvioinnista ja evaluoinnista oppiminen. Näin edetään yk- 
silön työstä työyhteisön käytäntöjen kautta organisaation työn kehittämiseen. Juuri edellä mainittujen oppimisprosessien edistäminen ja myös käytäntöön siirtäminen nähdään ratkaisevaksi työyhteisön oppimisen kannalta.

\section{Organisaatiokehittäjien} kannattaa perehtyä kirjan luvussa 4 esitettyihin tiedon prosessoinnin taksonomioihin. Kirjoittajat ovat perehty- neet viimeisimmän tietämystutkimuksen lähteisiin ja soveltaneet tätä ainesta monissa käsitteellisissä viitekehyksissä. Blackler' in, Hargadon \&

Sutton'in ja Nonaka'n kirjoituksia on arvioitu työyhteisön kehittämisen kontekstissa, myös kriittisessä valossa.

\section{Kirjan loppupuolella}

tuodaan esille monia käytännön esimerkkejä työyhteisöjen kehittämisestä ja esitellään myös menetelmällisiä työkaluja.

\section{Suosittelen kirjaa}

lämpimästi jokaiselle knowledge management -alueella toimivalle tutkijalle, kehittäjälle, kouluttajalle ja konsultille. Kirja soveltuu myös oivallisesti paitsi aikuiskasvatuksen myös erilaisten poikkitieteellisten opintojaksojen lähdekirjaksi.

Mikko Ruohonen 